\title{
Determination of Nitinol Fibers Performances by Means of Embedded Systems
}

\author{
Kadir SABANCI ${ }^{1}$, Murat KOKLU ${ }^{* 2}$, Serafettin EKINCI ${ }^{3}$ \\ Accepted $15^{\text {th }}$ August $2014 \quad$ DOI: 10.18100/ijamec.72204
}

\begin{abstract}
Utilization of shape memory alloys is rapidly spreading to many technological areas. From this point, alloys with shape memory are used in various fields such as temperature sensors in electronics, test valves in medicine, radiator fans in automotive and multi leg mobile robots. Application of nitinol fibers, which are actually shape memory alloys, as muscle fibers in industrial robots are increasing day by day. In this study, several tests were carried on aiming for the operational performance of nitinol fibers that are easy to control, economic, silent and harmless to environment and that have increasing utilization in recent motion technology. By using embedded systems, contraction (spasm) ratios and electrical current passing through the fibers were measured after 0.04 and 0.06 inch nitinol fibers were subjected to various voltages. Additionally, yielding limit value of nitinol fibers at split (breaking) point were detected. In the realized test system, ATmega 2560 microprocessor was took part as an embedded system in the Open Source Arduino Mega electronic card.
\end{abstract}

Keywords: Embedded systems, Nitinol, Shape memory alloys.

\section{Introduction}

Utilization of shape memory alloys is rapidly spreading to many technological areas. From this point, alloys with shape memory are used in various fields such as temperature sensors in electronics, test valves in medicine, radiator fans in automotive and multi leg mobile robots $[1,2]$.

Generally, when robot motion system was analyzed, most commonly used systems are hydraulic, pneumatic and electric motor systems which are called as traditional robot actuating arrangements [3].

Application of nitinol fibers, which are actually shape memory alloys, as muscle fibers in industrial robots are increasing day by day [4]. The biggest advantage of actuator system, which is working with the principle of nitinol temperature deformation, is simplicity. In this study, several tests were carried on aiming for the operational performance of nitinol fibers that are easy to control, economic, silent, harmless to environment and that have increasing utilization in recent motion technology. [5].

Shape memory effect in Nickel-Titanium (Ni-Ti) alloy has been discovered in United States in 1962 by W.J.Buehler and his friends in United States Marine Corps Warfighting Laboratory. This alloy which is under the trade name called as Nitinol (Ni-Ti Naval Ordnance Laboratory) shows very strong mechanical memory depending on deformation and temperature [6].

Small-scale computers which are embedded in non-computer devices are called as embedded systems [7, 8]. Embedded systems have more limited resources then regular computer's facilities [9]. For example, in personal computers; processor

\footnotetext{
${ }^{I}$ Karamanoglu Mehmetbey University, Faculty of Engineering, ElectricalElectronic Engineering Department, Karaman, Turkey

2 Selcuk University, Faculty of Technology, Computer Engineering, Department, Konya, Turkey

3 Selcuk University, Faculty of Technology, Machine Engineering, Department, Konya, Turkey

* Corresponding Author: Email: mkoklu@selcuk.edu.tr

Note: This paper has been presented at the International Conference on Advanced Technology\&Sciences (ICAT'14) held in Antalya (Turkey), August 12-15, 2014.
}

speed is gigahertz-GHz (109 hertz) and main memory is giga byte-GB (109 byte) level, in embedded systems; speed is mega hertz-MHz (106 hertz) and the memory is kilo byte-kB (103 byte) or mega byte-MB (106 byte) levels [10, 11, 12]. Embedded systems contain microcontroller which was designed for few special procedures, instead of a microprocessor $[7,8]$.

In this study, electrical current passing through the fibers on various voltages of 0.004 and 0.006 inch nitinol fibers were measured by using embedded systems. Arduino Mega 2560 electronic card was used as embedded system.

\section{Material}

When nitinol fibers was heated, it was stiffened up approximately $5-8 \%$ of its length. Most simple and easy way for heating to the Nitinol is to perform electric current with fiber connection. When current is applied, it generates heat. This heats the fiber and leads contraction. This method is known as ohmic heating. Nitinol does not return to their original length when it cools. It requires pretensioned force such as arc, to return to the original length [13]. In this study, 0.004 and 0.006 inch nitinol fibers were used (Figure 1). Important properties of the nitinol fibers which were used in the study were shown in Table 1.

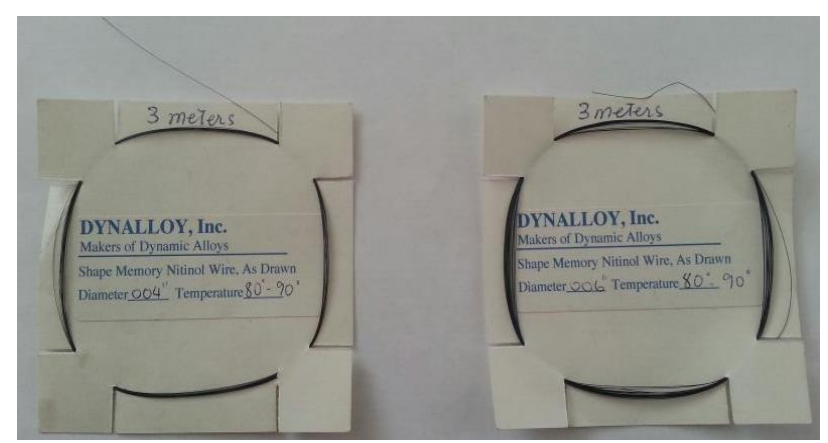

Figure 1. Nitinol fibers which used in practice

Arduino is physical programming platform which includes input / output cards and Java-based programming language. In Arduino 
development board which was produced by Atmel, C-based programming is performed with their own software Wiring program [15]. Arduino is an application written in the Java programming language which is serving as IDE code editor and compiler, at the same time it can perform installation process of compiled program to the card and it can be run on any platform. Ready-made cards can be purchased for usage of the Arduino which has open hardware and open-source architecture [16].

Table 1. Important properties of the 0.006 and 0.004 inch nitinol fibers [14]

\begin{tabular}{cccc}
\hline $\begin{array}{c}\text { Fiber Diameter } \\
\text { Size }\end{array}$ & $\begin{array}{c}\text { Resistance } \\
\text { Ohms } \\
\text { Per Inch }\end{array}$ & $\begin{array}{c}\text { Maximum } \\
\text { Pull/Force } \\
\text { (grams) }\end{array}$ & $\begin{array}{c}\text { Current at Room } \\
\text { Temperature }\end{array}$ \\
\hline $0.004 "$ & 3 & $150 \mathrm{~g}$ & $180 \mathrm{~mA}$ \\
$0.006 "$ & 1.3 & $330 \mathrm{~g}$ & $400 \mathrm{~mA}$ \\
\hline
\end{tabular}

The Arduino Mega 2560 is a product of Arduino family, which owns Atmega 2560 microcontroller [15]. Arduino Mega 256 development board is shown in Figure 2. General properties of the Arduino Mega 256 development board are given in Table 2.

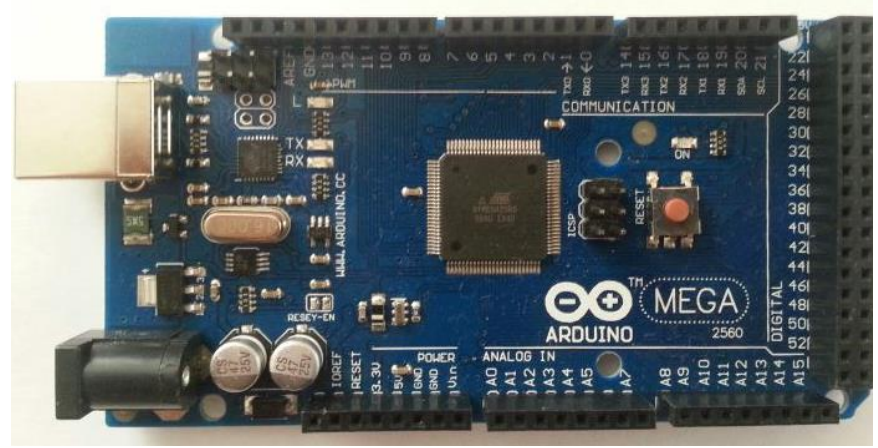

Figure 2. Arduino Mega 256 Development Board

Table 2. General properties of the Arduino Mega 256 [17]

\begin{tabular}{cc}
\hline \multicolumn{2}{c}{ GENERAL PROPERTIES } \\
\hline Microcontroller & ATmega2560 \\
Operating Voltage & $5 \mathrm{~V}$ \\
Supply Voltage & $7-12 \mathrm{~V}$ \\
(Recommended) & $6-20 \mathrm{~V}$ \\
Supply Voltage (Limits) & 54 (of $14 \mathrm{PWM}$ output) \\
Digital I/O Pins & 16 \\
Analog Input Pins & $40 \mathrm{~mA}$ \\
Output Current (per pin) & $50 \mathrm{~mA}$ \\
Output Current (3.3V) & bootloader) \\
Flash Memory & $8 \mathrm{~KB}$ \\
SRAM & $4 \mathrm{~KB}$ \\
EEPROM & $16 \mathrm{~Hz}$ \\
\hline
\end{tabular}

\section{Material}

Received signal from No. 13 PWM pin of Arduino Mega 256 control card is passed through from RC filter and converted to DC voltage. This voltage value ranging between $0-5 \mathrm{~V}$ is increased to $0-10 \mathrm{~V}$ with using the non-inverting amplifier gain 2 . After then, current value is increased by using common emitter transistor because current value of the signal is low at the output of Opamp. This obtained voltage is applied to the Nitinol fiber. In this system, by changing the rate of PWM. applied voltage to the
Nitinol fiber is controlled.

Voltage applied to the fiber is passed over from shunt resistor. Voltage drops to shunt resistor depending on the passing current. As the low value of voltage, it is increased to $0-5 \mathrm{~V}$ with noninverting amplifier. The output of these amplifiers is applied to the analog input and current values of the fiber is measured. Pin structure of Arduino Mega 256 control board is shown in Figure 3 , and circuit diagram of the system is shown in Figure 4.

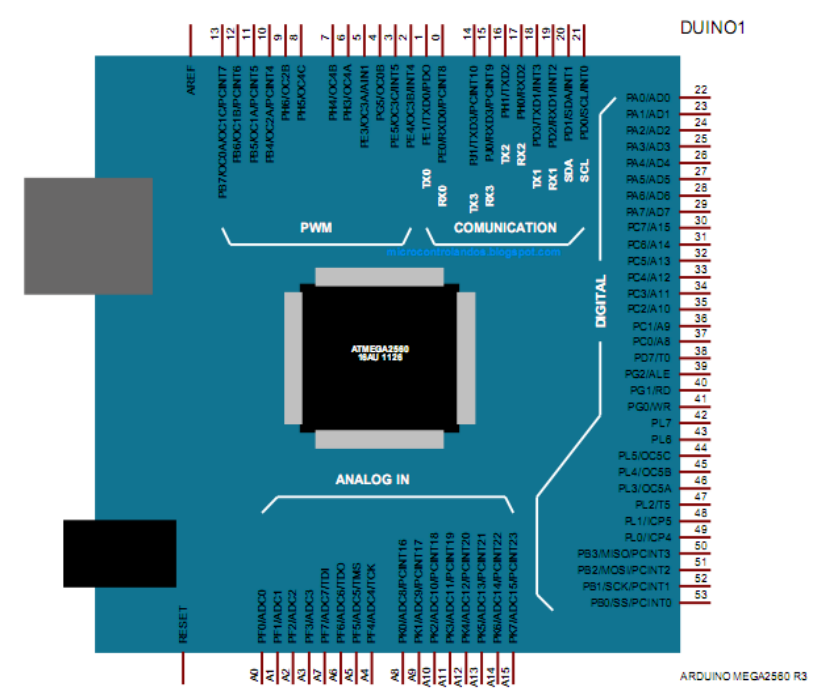

Figure 3. Pin structure of Arduino Mega 256

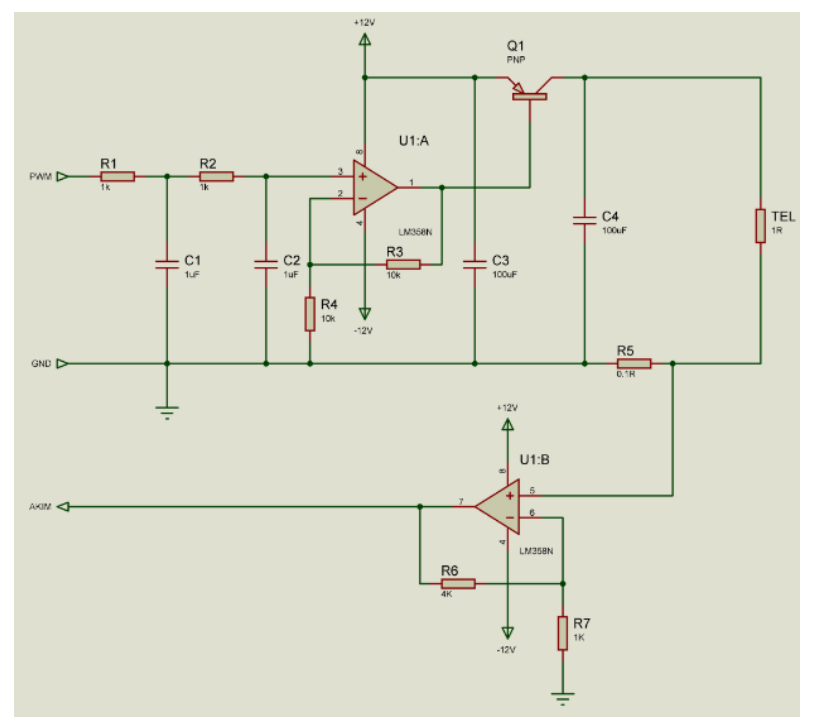

Figure 4. Circuit diagram

0.006 inch resistance of nitinol fiber is $1.3 \Omega$ per inch. Accordingly, the 250-mm resistance of nitinol fiber is calculated as $12.78 \Omega$. Resistance of 0.004 inch nitinol fiber, in the same size, is calculated as $29.52 \Omega$.

Applied voltage to the nitinol fiber and the measured current values are given in Table 3 . In accordance with these data informations resistance of nitinol fibers are calculated. 0.006 and 0.004 inch current and voltage of nitinol fibers graph are shown in Figure 5. 
Table 3. Applied voltage to the nitinol fiber and the measured current values

\begin{tabular}{ccccc}
\hline \multirow{2}{*}{ Voltage $(\mathrm{V})$} & \multicolumn{2}{c}{$0.006 "$} & \multicolumn{2}{c}{$0.004 ”$} \\
\cline { 2 - 5 } & Current $(\mathrm{A})$ Resistance $(\Omega)$ Current $(\mathrm{A})$ Resistance $(\Omega)$ \\
\hline 4.5 & 0.349 & 12.86 & 0.145 & 30.02 \\
5.5 & 0.419 & 13.12 & 0.182 & 30.24 \\
6.5 & 0.485 & 13.38 & 0.213 & 30.47 \\
7.5 & 0.553 & 13.56 & 0.244 & 30.68 \\
\hline
\end{tabular}

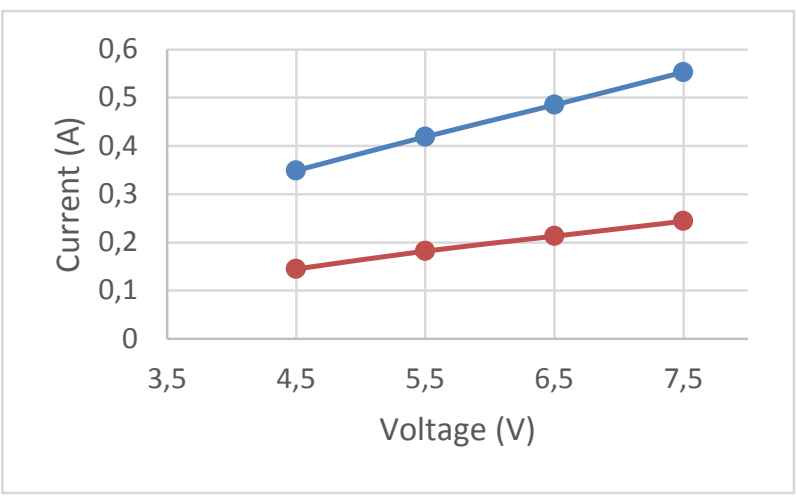

Figure 5. Current and voltage of nitinol fibers graph

When energy is given to 0.006 -inch and $250 \mathrm{~mm}$ length nitinol fiber with help of the Arduino Mega 256, nitinol fiber is stiffened up $13 \mathrm{~mm}$. Contraction of nitinol fiber was calculated as \%5.2. Amount of contractions when current passing on 0.006 inch nitinol fiber is $398 \mathrm{~mA}$ that is same as when amount of contractions is $640 \mathrm{~mA}$. Contraction takes place in less time only in large currents.

Deterioration is observed in the properties of fiber when current passing on 0.006 inch nitinol fiber reaches to $872 \mathrm{~mA}$. This value is defined as the yield limit. When the current value reaches 964 $\mathrm{mA}$, nitinol fiber is broken.

\section{Conclusion}

In this study, resistance values of nitinol fibers were determined by measuring to current values on fibers at different voltage values applied to 0.004 and 0.006 inch nitinol fibers, $250 \mathrm{~mm}$ in length, by using Arduino Mega 256 control board. Resistance value of $250 \mathrm{~mm}$ and 0.006 inch nitinol fiber at four different voltages $(4.5,5.5,6.5$, $7.5 \mathrm{~V})$ was averagely $13: 23 \Omega$, and for 0.004 inch nitinol fiber it was $30.35 \Omega$.

When voltage is applied to $250 \mathrm{~mm} 0.006$ inch nitinol fiber, length is contracted by approximately \%5.2. Nitinol fiber are contracted faster in the high voltage values. Yield point of 0.006 inch nitinol fibers was determined as 872 $\mathrm{mA}$.

\section{References}

[1] Dilibal S., Sönmez N., Dilibal H., "Ni-Ti Sekil Bellekli Alaşımlar ve Teknolojik Kullanım Alanları", 3. Uluslar arası İleri Teknolojiler Sempozyumu, 2003

[2] Dilibal S., Dilibal H., "Ituhand Robot El ve Mayın Temizleme Alanında Kullanılabilirliği”, Savunma Teknolojileri Kongresi, 2002

[3] Dilibal S., Güner E.,Akturk N., "Three-finger SMA Robot Hand and İts Practical Analysis", Robotica, 20,175-180, 2002

[4] Topbaş E., Akkuş N., "Şekil Hafizalı Alaşımlar ve Endüstriyel Uygulamaları", Makine Teknolojiler Elektronik Dergisi, Cilt 4 sayfa 15-22,2007

[5] Dilibal S.,Güner E., "Üç Parmaklı Şekil Bellek Alaşımlı(SMA) Robot Elin Yapımı ve Uygulama Analizi",Dokuz Eylül Üniversitesi Fen ve Mühendislik Dergisi,,Cilt 2,say1 1,159-173,2000

[6] Selimbeyoğlu E.,, "Design of shape memory alloy actuators", Ph. D. Thesis, METU Ankara,1992

[7] Catsoulis, J., "Designing Embedded Hardware", O2Reilly, 2005, pp. 26-28

[8] K. Prasad, V. Gupta, A. Dass, A. Verma, "Programming for Embedded Systems",2002, Wiley, pp. 15, 2.

[9] Çakır H.Ş., Özcanhan M.H. 2011. Gömülü Sistem Uygulamalarına Yapılan Saldırılar Ve A $\breve{g}$ Bağlantılı Gömülü Sistemlerin Güvenliğinin Sağlanmasi. ElektrikElektronik ve Bilgisayar Sempozyumu Bildiri Kitabi 120124. Elazı̆

[10] Topaloğlu, N., Görgünoğlu, S., "Mikroişlemciler ve Mikrodenetleyiciler", Seçkin Yayınevi, 2003, pp19-165.

[11] Özcerit, A. T., Çakıroğlu, M., Bayılmış, C., "8051 Mikrodenetleyici Uygulamaları", Papatya Yayıncılık, 2008, pp 14-24.

[12] Mazidi, M. A., Mazidi, J. G., McKinlay, R. D., "The 8051 Microcontroller and Embedded Systems", Prentice Hall (Peason), 2006, pp. 24-27.

[13] Sabanc1 K., "Yapay Kas Kullanılarak Örümcek Robot Tasarımı”, Yüksek Lisans Tezi, Selçuk Üniversitesi Fen Bilimleri Enstitüsü,Konya,2005.

[14] http://www.dynalloy.com/docs/TCF1140RevD.pdf

[15] Erdal AĞYOL,Melih KUNCAN, H. Metin ERTUNÇ, Özel Şifreli, Telefon Uyarımlı Ve Android Uygulamalı Araç Güvenlik Sistemi. 8.Mekatronik Tasarım ve Modelleme Kongresi Bildiri kitabı sayfa 11-20, 20 Eylül 2013, Ankara, Türkiye

[16] "Embedded System" Wikipedia, http://www.wikipedia.org/ wiki/Embedded_system

[17] http://arduino.cc/en/Main/arduinoBoardMega2560 